\title{
The Many Scripts of the Chinese Scriptworld, the Epic of King Gesar, and World Literature
}

\author{
Karen L. Thornber* \\ Harvard University \\ thornber@fas.harvard.edu
}

\begin{abstract}
The idea of an East Asian cultural "bloc" united in no small part by the Chinese script has long been widely held; through the end of the Qing dynasty Chinese characters served as the scripta franca for Chinese, Japanese, Korean, and Vietnamese intellectuals. Yet writing in East Asia has almost always involved more than Chinese characters and their offshoots. The purpose of this article is twofold. First is to introduce readers of world literature unfamiliar with East Asia to the wide variety of the region's languages and scripts. The second objective is to demonstrate that when we associate writing in China only with Chinese characters, as often has been the case, we overlook some of the region's, and the world's, most significant works of world literature. These include the twelfth-century Epic of King Gesar, a living epic which at twenty-five times the size of the Iliad is the world's longest.
\end{abstract}

\section{Keywords}

Alai - Epic of King Gesar - Iliad - Mahabharata - Mongolia - Tibet

The idea of an East Asian cultural "bloc" united in no small part by the Chinese script has long been widely held; through the end of the Qing dynasty (16441911) Chinese characters served as the scripta franca for Chinese, Japanese,

* Thank you to Mark Elliott, Shiamin Kwa, Steve Owen, Miya Xie Qiong, and three anonymous referees for sharing their expertise. A grant from the Harvard Asia Center assisted in preparing this article. 
Korean, and Vietnamese intellectuals. ${ }^{1}$ Yet writing in East Asia has almost always involved more than Chinese characters and their offshoots. The purpose of this article is thus twofold. First is to introduce readers of world literature unfamiliar with East Asia to the wide variety of languages and scripts present in the region. The second objective is to demonstrate that when we associate writing in China only with Chinese characters, as often has been the case, we overlook some of the region's, and the world's, most significant works of world literature. The article begins with an overview of language and script contestations within the borders of today's China. It then turns to the colorful transmission history of the twelfth-century Epic of King Gesar, which at twentyfive times the size of the Iliad is the world's longest epic. Gesar continues to thrive today in numerous oral forms and multiple languages and scripts, but despite its proliferation for centuries in Mongolian and Tibetan, it was translated only belatedly into Chinese. I conclude with thoughts on how Gesar, a central part of the lives of numerous peoples across Asia and beyond, has been neglected in world literature scholarship; and I invite us to include Gesar and other well-traveled but understudied texts in our new compasses of world literature.

The linguist Linda Tsung argues that "the different languages [and scripts] of the peoples of China's vast territories contested for supremacy as far back as the Archaic era" (34). For most periods "supremacy" is an overstatement, but across the millennia the territory of today's China has been home to multiple and often competing languages and scripts. There are a number of watershed events/periods in Chinese history that significantly changed the status and use of languages and scripts and that are crucial to understanding their complexity in East Asia. ${ }^{2}$

First, in order to integrate non-Han tribes into his empire, the Qin emperor Qin Shi Huang (260-210 BCE) devalued non-Han scripts; a number of prominent local scripts fell into disuse under the Qin's centralization and expansion policies (Tsung 36). The Qin policy of Chinese script unification (wenzi tongyi) itself standardized different variants of the Chinese script. The efforts of the Qin dynasty $(221-206 \mathrm{BCE})$ were followed by further script consolidation during the Han dynasty $(206 \mathrm{BCE}-220 \mathrm{CE})$ to ensure that local officials could read imperial

1 Chinese characters were also used to transcribe Mongolian and Manchu, facilitating trans-

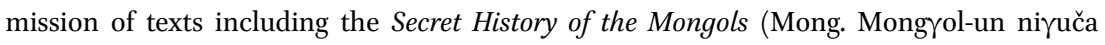
tobčiyan, c. 1228), the most celebrated "native" story of Genghis Khan (Chinggis, c. 1162-1227) (Thornber "Neglected").

2 Tsung identifies and elaborates on these events/periods (34-52); Zhou summarizes the multiple scripts present in China. 
edicts. A second important period was the introduction of Confucianism in the civil service examinations (121 BCE), revived by the Sui emperors (589-618) and refined during the Tang dynasty (618-907), which required Han and non-Han elites alike to master tens of thousands of Chinese characters. ${ }^{3}$ Non-Han students continued to learn non-Han languages and scripts, however, including at the Imperial College in Chang'an; familiarity with two or more languages and scripts was not uncommon among non-Han elites. Likewise, as Evelyn Rawski notes, in the following centuries, even while using Chinese characters for government decrees, the Liao (907-1125), Jin (1115-1234), Xixia (1038-1227), and Yuan (1279-1368) regimes also "created their own national scripts." To give one example, the tenth-century Khitan scripts served as the foundation for the twelfth-century Jurchen large and small scripts (Rawski "Reenvisioning" 837).

The third watershed event in language and script use was the Mongol conquest of Han Chinese peoples and establishment of the Yuan dynasty, where imperial edicts were written in Mongolian, and Mongolian, Arabic, and Persian held the highest status. ${ }^{4}$ But Chinese characters retained an instrumental value for Mongol rulers to communicate with local officials, albeit via a translation service since most Mongols were not proficient in the Chinese script. Although non-Han languages in the south and southwest of the empire, including Tibetan, had no official status, they were not suppressed by the Yuan court.

Han Chinese overthrew the Yuan in 1368, creating the Ming Dynasty, which itself was toppled in 1644 by non-Han Manchus who established the Qing Dynasty (1644-1911). A fourth landmark in language and script use occurred when Qing rulers required documents submitted to the emperor to use both Manchu and Chinese languages; academics not proficient in the Manchu script were demoted. Although Manchu was designated as the national language, the Qing also granted official status to Chinese, Mongolian, and Tibetan, and all four languages enjoyed a publishing boom. Multilingual materials were common, with Manchu often serving as a "bridge language" - "the language that Mongols and other non-Han peoples could use to access Chinese-language works" (Rawski “Qing Publishing” 324). Manchu was particularly convenient for the Qing's Mongol population, given the close connections between Manchu and Mongol writing systems. Even though translation of Chinese fiction and

3 The civil service examination system developed gradually over the centuries and was limited primarily to elites.

4 Haw reappraises the place of Persian in the Yuan, arguing that it was never a "genuine lingua franca" and instead was confined to commercial and official circles within the Muslim community (5). 
drama was officially prohibited, Chinese novels circulated widely, with some manuscripts featuring "phonetic transcriptions of Chinese texts in Manchu letters, so that they could be read aloud to bannermen who could not read Chinese but understood the spoken language" (319). Languages other than Chinese, Manchu, Mongolian, and Tibetan were generally prohibited during the Qing except for religious activities, including in southwest China the Dongba and Geba scripts of the Naxi people and the Yi script of the Yi people.

A fifth transformative period was the late nineteenth and early twentieth centuries, when Chinese worked on reforming their writing system, believing the Chinese script inconsistent with modernity. As Jing Tsu observes, "China almost lost its script just as its modern language was taking place .... Script inventors and language reformers ... responded with an array of imaginativeand at times esoteric - prescriptions." These included alphabet letters, shorthand, notations for deaf-mute persons, and numeral-based diagrams $(19,21){ }^{5}$ In addition, some Chinese also began to write prolifically in English and other European languages. ${ }^{6}$ The Qing and early Republican (1912-1949) periods likewise witnessed efforts by foreign missionaries to promote phonetic scripts among China's many minority groups. China's sixth historical watershed moment in language and script use was Japanese colonization of Taiwan in 1895 and enforcement of the Japanese language there, as well as in northeast China, where the Japanese established the informal colony of Manchukuo in 1932. ${ }^{7}$

In the decades since the Japanese defeat in 1945 and the founding of the People's Republic of China in 1949, the Chinese government has enforced changes to the Chinese script and enacted a broad array of policies toward the many languages and scripts of their minority peoples (Beckett and Postiglione, Tsung). At times Chinese authorities have encouraged or at least not impeded use of non-Chinese scripts—including Dongba and Geba, Dungan (Hui), Hangeul (Korean), Latin (for Bai, Bouyei, Hani, and others), Lisu, Miao, Mongol, Pai, "Women's Script" (nüshu, Hunan Province), Tai, Tibetan, Uyghur, Yi, and Zhuang ${ }^{8}$ - but in recent years Chinese officials have notably reduced and in

5 Romanization of the Chinese script dates to the Italian Jesuit priests Matteo Ricci (1552-1610) and Michele Ruggieri (1543-1607), who co-authored the first Portuguese-Chinese dictionaries.

6 Lin Yutang (1895-1976) is a principal early example. Needless to say, Chinese based outside China have written in countless languages and scripts.

7 For more on script use in Taiwan see Bachner.

8 Several of these scripts are used to write multiple languages, including the Tibetan script, which is of Indic origin and used, with adaptation, to write Tibetan languages, Dzongkha, 
certain sites even eliminated the teaching of ethnic minority languages (Bender, Wong "Tibetans", Zhou). Manchu, for instance, once the language of the Chinese empire, is now spoken only in a small corner of Xinjiang near the Kazak border, by the Xibe, with very few young Xibe able to read the Manchu script (Jacobs). The internet has also changed how Chinese write, with romanized Cantonese, Shanghaiese, Mandarin, and Taiwanese as well as numerous other languages readily found online (Mair $54-56$ ). ${ }^{9}$

Over the millennia, as classical Chinese literature flourished, many of China's numerous non-Chinese scripts were also used to write creatively. While to the east and southeast, Japanese, Koreans, Vietnamese, and later Taiwanese developed literatures in Chinese characters and their offshoots, ethnic minorities across what is today's China developed vibrant creative traditions written for the most part in separate and often multiple languages and scripts. Among these, most notable are China's Mongolian, Uyghur, and Tibetan peoples, whose literatures bespeak a creative efflorescence well beyond the pale of Han Chinese culture (Bender). An especially remarkable example of this literary flowering is the twelfth-century Epic of King Gesar (Tb. gLing Gesar, lit. Gesar of gLing). Just as there is no one definitive title, ${ }^{10}$ so too is there no single official version or even a standard collection of versions of this text. A living epic that continues to circulate broadly worldwide in multiple Central, East, South, and Southeast Asian as well as Eastern and Western European languages and scripts, Gesar is a massive and constantly changing narrative; as codified in its most complete Chinese version, the epic comes to some 20 million words of poetry and prose in 120 volumes. ${ }^{11}$ Yet this narrative is barely known among scholars of East Asian literatures, much less among scholars of world literature. The following pages therefore first summarize the background and story of Gesar and then discuss several of the major languages and scripts in which it has appeared, both in East Asia and in the West; I note some of the fundamental

Sikkimese, Ladakhi, and sometimes Balti, and the Mongolian script, which comes from Old Uyghur and has been used, with adaptation, to write Mongolian, Buryat, Kalmyk, Oirat, Manchu, Xibe, and others. Many languages in China, including Mongolian, have used multiple scripts.

9 Mair also outlines the use of Roman letters in modern Chinese-language literature (5455).

10 Thank you to Norzin Dickyi for this observation.

11 Robin Kornman and a team of translators are currently working on a "complete" English translation based on a typewritten copy in Tibetan script, which itself comes from a woodblock carved in Eastern Tibet (Lama xiii). When in Tibet, Kornman taped hundreds of hours of performances of Gesar and of discussion of the epic (McLemee). 
changes to the epic as it migrated among peoples, languages, and scripts. The article concludes with a brief discussion of Gesar's place in world literature.

Expounding on the heroic deeds of the seventh-eighth century Gesar, the legendary King of Gling, Gesar consists of a series of narrative songs centering on Gesar's battles against enemies of the dharma and success in bringing order to the land. ${ }^{12}$ In most of its versions the epic follows Gesar from his miraculous birth and early years to his acquiring supernatural weapons, armor, and horse, as well as a beautiful wife (or wives), through his countless military campaigns and battles with demons on behalf of his family, people, and other communities, to his departure to another realm.

Gesar generally is believed to have been transmitted orally beginning in the twelfth century. ${ }^{13}$ Parts of the epic likely were codified in the Tibetan language and script as early as the fifteenth century (Maconi 374), but the earliest extant handwritten version dates to 1779, transcribed in Tibetan, using Tibetan script (Yang 294). The first printed version, which contained only seven chapters, was produced in Beijing in 1716, but in neither the Tibetan nor the Chinese language or script. Instead, it appeared in the Mongolian language and script, commissioned by the Qing Emperor Kangxi (1654-1722). ${ }^{14}$ Interestingly, the top of every page of the 1716 Mongolian version contains the Chinese characters for Sanguozhi, mistakenly labeling the text a copy of the celebrated fourteenthcentury Chinese historical novel Romance of the Three Kingdoms (Sanguozhi tongsu yanyi) (Ratcliffe), what later became one of the nation's so-called Four Great Masterpieces (si da mingzhu).

The 1716 and other Mongolian (including Buryat) and Tibetan language and script versions of Gesar have much in common, but not surprisingly, they are also informed by numerous indigenous tales, folklore, and mythology, as well as popular religious beliefs including different forms of Buddhism and local histories familiar to varying Mongolian and Tibetan communities, respectively. More notably, the 1716 Mongolian version has Gesar summoned from Tibet to China to bring solace to its grieving ruler and restore peace to

12 Much Gesar scholarship both in China and abroad has focused on the historical accuracy of the tale, including the relation of Gesar to the Tibetan King Trison Deutsen (c. 742-797) (Li).

13 Today the story is recited by professional bards — literate and illiterate — throughout Tibet, as well as in neighboring countries including Nepal, India (Ladakh), Mongolia, Russia, and elsewhere in central Asia, in addition to numerous ethnic groups within China such as the Bai, Lisu, Mongols, Naxi, Pumi, Tu, and Uyghur (Bender 1045).

14 It has been argued that the 1716 Mongolian edition is a transcription of oral stories circulating in Qinghai (western China) in the 1630s (Rawski "Qing Book" 220). 
the kingdom. ${ }^{15}$ Furious that Gesar removes his deceased wife from his grasp while he is sleeping, China's emperor attempts to destroy him by casting him into the Hole of Wasps, the Pit of Serpents, and the Den of Wild Beasts. Gesar survives these trials unscathed, so the emperor has him taken to the ramparts to be executed. But shortly before the first spear is thrown, Gesar releases his parrot, which he commands to fly to Tibet and order his brother to raise an army to destroy China to avenge his (Gesar's) death. Terrified, the emperor of China not only spares Gesar's life but also grants Gesar his daughter in marriage and agrees to take another wife himself, thereby bringing order to the realm. After spending three years in China, Gesar returns home to Tibet.

The Mongolian chapter on visiting China stands out in an epic replete with heroic battle scenes, demon slaying, and subjugating opponents. It also has little resonance with oral and written Tibetan-language versions of Gesar, which when they include a visit to China, tell a very different story. For instance, in the Lower Ladakh (western Tibet, northern India) version of the text, transcribed into Tibetan script between 1905 and 1909 by the Moravian missionary August Hermann Francke (1870-1930), Gesar also travels to China. ${ }^{16}$ But whereas the Mongolian version remains relatively silent about the journey itself, the Lower Ladhki version depicts travel to China as treacherous and Gesar as relying on his superhuman powers to overcome a series of punishing obstacles. Furthermore, whereas in the Mongolian version Gesar brings order to China, in the Tibetan version he afflicts all of China with leprosy. The Tibetan version emphasizes Tibet's distance from as well as its potential destructive power over China.

Gesar first caught Western attention in the 1770s, when the German zoologist and botanist Peter Simon Pallas (1741-1811) spoke of the Temple of Gesar in his travelogue Reisen durch verschiedene Provinzen des Russischen Reichs (Travel through Different Provinces of the Russian Empire, 1771-76) (Hummel). Three decades later, in his ethnographic Nomadische Streifereien unter den Kalmüken

15 Tibet was part of China during the Yuan dynasty, when the epic is believed to have originated, but during the seventh and eighth centuries, when the epic is likely set, the Tibetan empire stretched far into today's China as well as Central and South Asia.

16 Francke was one of a number of nineteenth- and twentieth-century Europeans who recorded local performances of Gesar. Also noteworthy was the Belgian-French Alexandra David-Néel (1868-1969) and her adopted stepson Arthur Yongden (Lama Yongden), who collected pieces of oral performances of Gesar in eastern Tibet which they then adapted into French as La vie surhumaine de Guésar de Ling, le héros tibétain (The Superhuman Life of Gesar of Ling, Tibetan Hero, 1931). Three years later their retelling was translated into English and published in London. Like many Tibetan versions, David-Néel's does not include Gesar's visit to China. I discuss Western translations of Gesar in more depth below. 
in den Jahren 1802 und 1803 (Nomadic Rambles among the Kalmuks in 1802 and 1803, 1804), Benjamin Bergmann summarized in German some of the Kalmyklanguage versions of Gesar, marking the first appearance of the epic in a European language; Kalmyk was originally written in the Uyghur script and then between the sixteenth and early twentieth centuries in Clear Script (an adaptation of the Classical Mongolian alphabet). As its title Bokdo Gässärchan:Eine mongolische Religionsschrift in 2 Büchern (Lord Gesar: A Mongolian Religious Writing in Two Books, 231-84) suggests, Bergmann's translation emphasized religious elements of the tale. Some years later, in 1836 , the Moravian missionary and Mongolian and Tibetan specialist Isaac Jacob Schmidt (1779-1847) prepared a new edition of Gesar in Mongolian, which he then translated into German as Die Thaten Bogda Gesser Chan's, des Vertilgers der Wurzel der zehn Übel in den zehn Gegenden. Eine ostasiatische Heldensage (The Deeds of Lord Gesar: Eradicator of the Root of the Ten Evil Things in the Ten Regions-An East Asian Epic) and published in St. Petersburg and Leipzig in 1839. Bergmann's and Schmidt's versions provided the basis for the epic's first English translation, Ida Zeitlin's Gessar Khan, published in New York nearly a century later $(1927) \cdot{ }^{17}$

As Zeitlin notes, nineteenth- and early twentieth-century Western-language translators of Gesar were particularly captivated by the epic as a source of "living material, hitherto inaccessible to Europeans, on the modes of speech and matters of life of the nomad tribes" (vi), and their renditions accentuated these aspects of the tale. But they also embraced Gesar's supernatural features. Especially noteworthy is how Zeitlin's nine-chapter translation expands on Schmidt's seven chapters to create a text that a contemporary reviewer called "intoxicating to the imagination and comparable in splendor to the Arabian Nights" (Ewing 204). For instance, Zeitlin includes more on Gesar's battles with the twelve-headed monster. She also wraps up the translation with Gesar having "uprooted the tenfold evil and restored gladness to the hearts of men ... [he ruled] over his people as the sun rules in the heavens and as the mountain rules over the valley below" (200), overshadowing Schmidt's ending, which describes Gesar's journey to the underworld to rescue his mother followed by his successful homecoming.

Even though Gesar existed in the Tibetan and Mongolian languages for centuries in various regions of today's China, and in Western languages since the early 1800 s, it was only in 1934 that the epic first appeared in Chinese,

17 Francke's text includes an English-language summary of Gesar, but Zeitlin's was the first book-length Gesar in a Western language. 
when the Tibetologist Ren Naiqiang, generally credited as China's first Han Chinese scholar of Gesar, translated a section into Chinese. Naming the epic Man sanguo (The Foreign Version of the Three Kingdoms), Ren posited it as a "foreign" version of China's Romance of the Three Kingdoms (Maconi, 389-90). In so doing, he signaled both Gesar's importance and its marginalization from classical Chinese literature; despite its strong impact in many parts of Asia, Gesar does not appear to have been known to classical (Han) Chinese writers.

Subsequent Chinese-language translations of Gesar were based on Mongolian, Tibetan, and even European-language versions. To give one example of the latter, in 1948 Chen Zongxiang published a Chinese-language translation of two sections of David-Néel's version (Maconi 390). Chinese-language studies of Gesar soared in China in the 1950s, following the founding of the People's Republic of China, with scholars and other investigators fanning out to the far reaches of the nation to collect materials from China's dozens of ethnic minorities. Significantly, just as Gesar began to appear more frequently in Chinese, additional versions were being published, with state sponsorship, in Mongolian and Tibetan. Work on Gesar came to a near halt during the Cultural Revolution of 1966-1976 (Robin 149), but the 1980s witnessed the first sustained effort to produce quality Chinese-language translations of the epic. Wang Yinuan's multivolume 1980 Gesa'er wang zhuan (Tale of King Gesar) was pioneering in this regard, although like most versions it is greatly abridged. In the preface to one of the volumes, Wang proclaims that this "heroic epic" not only is known throughout China but also is one of the world's "monumental works," and he points out to his readers that it is many times longer than the Indian Mahabharata (1). ${ }^{18}$

Today, in addition to being a massive scholarly enterprise in China, Gesar is also a thriving cultural industry, with additional translations into both Chinese and Tibetan, DVDs, and a steady stream of films and cartoons. ${ }^{19}$ The Chinese government even has used Gesar as proof that Hegel was mistaken when he asserted that there is no national epic in China, one website arguing that Gesar overturns "the long-held academic belief that Chinese writers have never created a Chinese epic. In fact, China boasts the longest epic in the world"

18 Chinese authorities also sought to bring Gesar to the attention of the Chinese public through popular culture; open air performances became frequent in the 1980s, and in 1990 Chinese state television broadcast eighteen episodes of the epic (Maconi 397).

19 For more on Han Chinese interest in and manipulation of Gesar and Tibetan culture, including the "Tibet craze," (Xizang re) see Buffetrille, Raine, Upton, and Wong "Showcase." 
(Raine). ${ }^{20}$ Some have accused these projects of cultural imperialism, as part of Han Chinese efforts to manipulate and profit from Tibetan and other minority cultures, despite the active participation of ethnic Tibetans and Mongolians in recording Gesar performances and collecting written materials related to the epic. But contemporary creative works such as the ethnic Tibetan Chinese writer Alai's (1959-) Chinese-language novel Gesa'er wang (King Gesar, 2009) reveal a much more complicated dynamic.

Alai's King Gesar brings the Epic of King Gesar to modern times, intertwining history, myth, and fiction. The novel depicts Gesar as a celestial being who is sent down from heaven to relieve people of their suffering (kunan de renjian, 30) and who haunts Jigmed, a contemporary shepherd turned storyteller. Gesar vanquishes various pockets of evil, after which he quickly becomes bored with the apparent tranquility of earthly life. Yet despite Gesar's successes and his belief that all has been resolved, the novel repeatedly emphasizes that human suffering continues. Among those in distress are the people of Qieguo (a small tribal power that clashed with Gling), whose emperor blacks out the sun, forcing his subjects to live in darkness. Furious that one of Gesar's generals wins a horserace against one of his generals and that Gesar spirits away the deceased empress's body, the emperor of Qieguo subjects him to four trials. But rescued by birds, scorpions, and even vegetation, Gesar emerges victorious, ultimately dispelling the demons, stabilizing the country, and even having the emperor offer him his throne. Howard Goldblatt's English version of Alai's King Gesar (trans. The Song of King Gesar) rewrites the Qieguo episode as a visit to China by replacing "Qieguo" (伽國) with "China." The English version thus changes the meaning of the Chinese version; it depicts China not only as a minor kingdom blanketed in darkness - an allusion perhaps to China's severe pollution - but even more controversially, as powerless to subdue a Tibetan king. ${ }^{21}$ Both the Chinese and the English versions of Alai's King Gesar conclude shortly thereafter with the reassurance, or threat, that even though Gesar ultimately leaves earth for good, "The story of his heroic deeds continues to be told" (353). Gesar flees to a more permanent heavenly tranquility, but his powerful impact on earth endures.

More than half a century ago, in "Faut-il reviser la notion de Weltliteratur?" (Do We Have to Revise the Notion of World Literature, 1964), French litera-

20 Gesar typically has been considered not a Chinese, or even East Asian epic, but rather an Inner Asian epic, of which there are many, with far more ties to the Turkish Dede Korkut than to anything in Han Chinese literature. Thank you to Steve Owen for this insight.

21 These elements are not included in Alai's Chinese version, tacitly or otherwise; unlike many early versions of the epic, Alai's Chinese version does not have Gesar travel to China. 
ture scholar René Étiemble (1909-2002) stridently criticized relentless Eurocentric constructions of world literature and pleaded with the field to broaden its perspective. Among the many examples he gives of Eurocentrism is the absence of Gesar in Elizabeth Frenzel's Stoffe der Weltliteratur: Ein Lexikon dichtunggeschichtlicher Längsschnitte (Themes of World Literature: A Longitudinal Literary-Historical Lexicon, 1962). Yet ironically, what troubles Étiemble is not that Frenzel failed to discuss Gesar as an example of world literature, but instead, himself succumbing to Eurocentrism, that she failed to speak of the epic in her article on Cäsar (Julius Caesar): "I looked in vain for any reference to the Tibetan Gesar, an epic on which a lot of work had been done ... And yet this is an exciting theme: a Roman Emperor that dominates the great epic of Tibet!" (98). ${ }^{22}$

Much has changed in the last fifty years, with European texts and languages still disproportionately favored in world literature scholarship but writing from other parts of the globe having made significant inroads. Just as Chineselanguage texts, including classical Chinese poetry, the Four Great Masterpieces, and works by celebrated modern writers such as Lu Xun (1881-1936) and Mo Yan (1955-), have garnered substantial attention, so too have contemporary ethnic Tibetan writers, including Tashi Dawa (1959-) and Alai, who publish in Chinese, and Jamyang Norbu (1949-), who publishes in English. ${ }^{23}$ Yet Gesar's sheer size, unwieldiness, and complexity, and perhaps too, paradoxically, its presence across numerous diverse places, languages, and scripts for centuries combined with its longtime status as an outsider to the Han literary tradition have heretofore excluded it from canons of world literature.

This article has outlined the proliferation of languages and scripts within the borders of today's China, demonstrating that writing there has nearly always involved more than the Chinese language and characters. More important, it has revealed that when we associate writing in China only with Chinese characters, we neglect one of the planet's most dynamic works of world literature. Many of Gesar's translators have likened this text to the Iliad, Aeneid, Arabian Nights, Song of Roland, Mahabharata, and Romance of the Three Kingdoms. The time has come to give Gesar the same attention in our own scholarship. So

22 Specialists believe a connection exists between Gesar and Caesar (Orofino 175), among other heroic figures such as Genghis Khan and Guandi (the mythical Chinese god of war), but not that Gesar is actually about the Roman emperor.

23 As suggested by the global preference for Chinese- and English-language Tibetan writers, the importance of the Tibetan language to Tibetan literature is sometimes minimized (Hartley and Schiaffini-Vedani; Venturino Contemporary; Venturino "Where"). 
doing promises to bring into clearer perspective global histories of the epic and the fluid dynamics of transcultural negotiation both within and far beyond the modern multi-ethnic nation-state. It also promises to invite renewed respect for Gesar as an opus of near unmatched scope and unsurpassed scale. And it reminds us of the humbling task we face as we seek to engage with the multiplicity of texts that, however neglected in certain circles today, are consummate works of world literature.

\section{Works Cited}

Alai. Gesa'er wang (King Gesar). Chongqing: Chongqing Chubanshe, 2009.

Alai. The Song of King Gesar. Trans. Howard Goldblatt and Sylvia Li-chun Lin. London: Canongate, 2013.

Bachner, Andrea. "Cultural Margins, Hybrid Scripts: Taiwanese Writing between the Global and the Indigenous." Journal of World Literature 1: 2 (2016), 225-243.

Beckett, Gulbahar H. and Gerard A. Postiglione. China's Assimilationist Language Policy: The Impact on Indigenous/Minority Literacy and Social Harmony. New York, NY: Routledge, 2012.

Bergmann, Benjamin von. Benjamin Bergmann's Nomadische Streifereien unter den Kalmüken in den Jahren 1802 und 1803 . Riga: C.J.G. Hartmann, 1804-1805.

Bender, Mark. "Ethnic Minority Literature." In The Columbia History of Chinese Literature, ed. Victor Mair. New York, NY: Columbia UP, 2001, 1032-54.

Buffetrille, Katia. "May the New Emerge from the Ancient? May the Ancient Serve the Present!' The Gesar Festival of Rma chen (A mdo 2002)." The Tibet Journal 34/35: 3/2 (2010), 523-54.

David-Néel, Alexandra and Lama Yongden. La vie surhumaine de Guésar de Ling, le héros tibétain. Monaco: Éditions de Rocher, 1978.

Étiemble, René. "Do We Have to Revise the Notion of World Literature?" In World Literature: A Reader, ed. Theo D'haen et al. New York, NY: Routledge, 2013, 93-103.

Ewing, Marion. “China in Children's Books." The Elementary English Review 11: 8 (1934), 203-5, 226.

Francke, August Hermann. A Lower Ladakhi Version of the Kesar-saga: Tibetan Text, Abstract of Contents, Notes, and Vocabulary of the New Words and Phrases. Calcutta: Asiatic Society, 1905-1909.

Hartley, Lauran R. and Patricia Schiaffini-Vedani, eds. Modern Tibetan Literature and Social Change. Durham: Duke uP, 2008.

Haw, Stephen G. "The Persian Language in Yuan-Dynasty China: A Reappraisal." East Asian History 39 (2014), 5-32.

Hummel, Siegbert. "Anmerkungen zur Ge-sar-Sage." Anthropos 54: 3/4 (1959), 517-35. 
Jacobs, Andrew. "Manchu, Once a Language of Empire, Nears Extinction." The New York Times 12 January 2016 ed.: A4, A10.

Jingme, Hortsang. "Tibetan Literature in the Diaspora." In Modern Tibetan Literature and Social Change, eds. Lauran R. Hartley and Patricia Schiaffini-Vedani. Durham: Duke UP, 2008, 281-300.

Lama Chönam et al. "Preface." In The Epic of Gesar of Ling: Gesar's Magical Birth, Early Years, and Coronation as King. Trans. Robin Kornman et al. Boston, MA: Shambhala, 2012, xiii-xiv.

Li, Lianrong. "History and the Tibetan Epic Gesar." Oral Tradition 16: 2 (2001), 31742.

Maconi, Lara. "Gesar de Pékin? Le sort du Roi Gesar de Gling, héros épique tibétain, en Chine (post-)maoïste." In Formes modernes de la poésie épique:nouvelles approaches, ed. Judith Labarthe. New York, NY: Peter Lang, 2004, 371-420.

Mair, Victor H. "Language and Script." In The Columbia History of Chinese Literature, ed. Victor Mair. New York, NY: Columbia UP, 2001, 19-57.

McLemee, Scott. "A Scholar Tackles a Tibetan Epic That Is Millions of Words LongWith Only a Fraction of Them on Paper." The Chronicle of Higher Education Online. Web. 17 Jan. 2003.

Mullaney, Thomas S. Coming to Terms with the Nation. Berkeley, CA: University of California Press, 2011.

Orofino, Giacomella. "A Note on Some Tibetan Petroglyphs of the Ladakh Area." East and West 40:1/4 (1990), 173-200.

Raine, Roberta. "Translation and Appropriation of the World's Longest Epic: Tibet's Gesar of Ling." Forum 12: 2 (2014), 65-85.

Ratcliffe, Jonathan. "Table of Mongolian Geser Khan Epic Variants." Web. 22 Mar. 2016. Rawski, Evelyn S. "Reenvisioning the Qing: The Significance of the Qing Period in Chinese History." The Journal of Asian Studies 55: 4 (1996), 829-50.

Rawski, Evelyn S. "Qing Book Culture and Inner Asia." In Books in Numbers: Seventyfifth Anniversary of the Harvard-Yenching Library, ed. Wilt L. Idema. Cambridge, MA: Harvard-Yenching Library, 2007, 197-235.

Rawski, Evelyn S. “Qing Publishing in Non-Han Languages.” In Printing and Book Culture in Late Imperial China, eds., Cynthia J. Brokaw and Kai-wing Chow. Berkeley: University of California Press, 2005, 304-31.

Robin, Françoise. “'Oracles and Demons' in Tibetan Literature Today: Representations of Religion in Tibetan-Medium Fiction." In Modern Tibetan Literature and Social Change, eds. Lauran R. Hartley and Patricia Schiaffini-Vedani. Durham: Duke UP, 2008, 148-70.

Thornber, Karen Laura. "Neglected Texts, Trajectories, and Communities." Symposium (2016), (forthcoming).

Tsu, Jing. Sound and Script in Chinese Diaspora. Cambridge, MA: Harvard UP, 2010. 
Tsung, Linda. Minority Languages, Education and Communities in China. New York, NY: Palgrave Macmillan, 2009.

Upton, Janet L. “The Politics and Poetics of Sister Drum: 'Tibetan' Music in the Global Marketplace." In Global Goes Local: Popular Culture in Asia, ed. Timothy J. Craig and Richard King. Honolulu, HI: University of Hawai'i Press, 2002, 99-109.

Venturino, Steven J., ed. Contemporary Tibetan Literary Studies. Boston, MA: Brill, 2007. Venturino, Steven J. "Where is Tibet in World Literature." World Literature Today 78: 1 (2004), $5^{1-56 .}$

Wang Yinuan. “Qianyan.” In Gesa'er wang zhuan. Xiang fu yao mo zhi bu (The Story of King Gesar: The Part on Taming the Evil Spirits). Trans. Wang Yinuan. Lanzhou: Gansu Renmin Chubanshe, 1980, 1-2.

Wong, Edward. “A Showcase of Tibetan Culture Serves Chinese Political Goals." The New York Times 20 Dec. 2015, A12.

Wong, Edward. "Tibetans Struggle to Salvage Fading Culture in China." The New York Times 29 Nov. 2015, A6.

Yang, Enhong. "On the Study of the Narrative Structure of Tibetan Epic: A Record of King Gesar." Oral Tradition 16: 2 (2001), 294-316.

Zeitlin, Ida. Gessar Khan. New York: George H. Doran Co., 1927.

Zhou, Youguang. "The Family of Chinese Character-Type Scripts." Sino-Platonic Papers 28 (1991). Web. 2 March 2016. 